https://journal-computing.org/index.php/journal-cisa/index

\title{
Model Pedukung Keputusan Dengan Metode Analitycal Hierarchy Process: Studi Kasus Proses Bongkar Muatan Barang Kapal
}

\author{
Ari Muzakir \\ Informatics Departement, Universitas Bina Darma, Palembang, Idnonesia \\ Email: arimuzakir@binadarma.ac.id
}

\begin{abstract}
As a center for leaning ships, the Port is a center that plays an important role as a facility that can connect one island to another in trading activities. In this study emphasizes the final goal of (1) determining the factors used as criteria for determining the right and optimal loading decisions, (2) calculating the priority weights of the decision criteria, (3) determining priority weights, (4) obtaining a design that best in priority ship unloading. In this study we use hierarchical based analysis methods or commonly called Analytical hierarchy process (AHP). This method performs pairwise comparisons between criteria and sub criteria by producing a criteria value matrix and produces consistent information each factor from the sub-criteria assessed where the $\mathrm{CR}<0.1$. The results of the scores for each 3 respondents are where the arrival time of the ship scores a total of 17.46 with the highest score, the type of load total score of 11.89 , the type of ship the total score is 6.61 and the total loading score of 3.05 .
\end{abstract}

Keywords: Analytical hierarchy process, decision support model, loading and unloading priorities.

\section{PENDAHULUAN}

Pelabuhan menjadi suatu sentra penghubung yang penting dalam moda transportasi laut untuk kegiatan perdagangan dan aktivitas ekonomi yang dapat menghubungkan antar pulau Kegiatan usaha proses pembongkaran isi muatan kapal di PT. Pelabuhan Indonesia II (Persero) Cabang Palembang yakni bidang penyediaan fasilitas dan jasa pelabuhan untuk proses pembongkaran isi kapal (barang) dan peti kemas, penyediaan jasa pergudangan dan penyimpanan barang secara intensif. 
Vol. 2, No. 2, May 2021 e-ISSN: 2775-2496

https://journal-computing.org/index.php/journal-cisa/index

Proses kegiatan bongkar muat isi muatan kapal yang saat ini terjadi yaitu dimulai dengan melihat dari sebelum kapal berlabuh untuk memastikan proses pembongkaran oleh petugas pelabuhan. Adapun yang menjadi prioritas bongkar muatan ini dilihat dari waktu kedatangan dan isi muatan kapal sesuai dengan kondisi gudang nanti. Namun dalam hal ini juga, proses pembongkaran tidak sertamerta melihat kapal barang yang sudah datang pertama kali akan tetapi juga akan melihat kondisi ketersediaan gudang. Selain itu juga, jenis muatan kapal juga menjadi pertimbangan untuk dilakukan pembongkaran muatan terlebih dahulu. Kondisi gudang yang tidak tersedia akan berpeluang banyaknya antrian kapal untuk meminta di bongkar muatannya walaupun kondisi dermaga dalam keadaan kosong. Selain itu juga, penentuan rute dalam proses bongkar muatan kapal juga berpengaruh untuk memberikan ketepatan dalam proses ketika kapal bersandar nantinya [1]. Hal ini menjadi suatu temuan mengenai aturan penjadwalan yang belum baik di Pelabuhan ini.

Untuk mengatasi permasalahan yang terjadi maka diperlukan prioritas bongkar muat yang bertujuan untuk mengurangi demurrage (antrian bongkar muat) dan pencegahan masalah. Dalam kasus ini, sistem pendukung keputusan dibutuhkan untuk mempercepat, mempermudah dan transparansi proses pengambilan keputusan [2], sehingga proses bongkar muat dipelabuhan dapat berjalan dengan lancar dan optimal.

\section{PENELITIAN TERKAIT}

Penelitian yang terkait dalam topik ini juga pernah dilakukan sebelumnya dengan tema dasar pemilihan pemasok (supplier) dan penentuan anggaran pembiayaan bahan baku di CV karya bahari surabaya. Metode Analitycal hierarchy process (AHP) yang dipakai untuk penilaian terhadap supplier dan juga sebagai penentuan anggaran bahan baku. Adapun proses penilaian supplier dilakukan dengan melihat dari segi pengukuran dan response time, sehingga dapat ditentukan supplier mana yang dapat dipilih [3].

Kemudian penelitian lainnya dengan tema penentuan prioritas pembangunan pelabuhan di kabupaten mukomuko dengan metode Analitycal hierarchy process. Penelitian ini menggunakan metode $A H P$ untuk mencari dan menentukan prioritas jenis pelabuhan dan lokasi atau tempat yang tepat untuk dibangun. Pada penelitian ini variable yang dipakai meliputi faktor kelautan, perikanan, transportasi, tata ruang dan 
https://journal-computing.org/index.php/journal-cisa/index

lingkungan yang tersedia. Sehingga hasil dalam penelitian tersebut menunjukkan pelabuhan mana saja yang dapat digunakan sebagai pelabuhan penyebrangan dan pelabuhan bongkar barang [4]. Penelitian lainnnya yang terkait yaitu sistem penentuan supplier kawat las dengan AHP dan TOPSIS untuk mencari perusahaan mana yang paling berpeluang untuk menjadi supplier kawat las dengan melihat sesuai dengan kriteriakriteria yang ditentukan [5].

Sedangkan pada penelitian yang dilakukan adalah melakukan perancangan model pendukung keputusan berdasarkan prioritas untuk proses bongkar muat kapal yang bersadandar di PT. Pelabuhan Indonesia II (Persero) Cabang Palembang dengan metode AHP digunakan untuk menentukan prioritas kapal yang perlu didahulukan untuk dibongkar.

\section{METODE PENELITIAN}

Proses analisa kebijakan butuh suatu kriteria yang nantinya dipakai sebelum menentukan pilihan alternatif yang tepat. Kriteria tersebut nantinya dipakai sebagai bentuk definisi suatu masalah yang terkadang dianggap sebagai tujuan akhir [6]. Analisa atas kriteria penilaian dilakukan untuk mendapatkan standar umum dalam proses pengukuran yang selanjutnya digunakan sebagai alat ukur untuk membandingkan alternatif yang ada [7],[8].

\subsection{Analitycal hierarchy process (AHP)}

AHP merupakan suatu model pendukung keputusan yang menggambarkan masalah multi-faktor yang kompleks atau multi-kriteria dalam hierarki [9]. AHP merupakan teknik pengambilan keputusan atau optimasi multivariate yang digunakan dalam analisis kebijaksanaan. AHP sering digunakan sebagai metode pemecahan masalah dibanding dengan metode yang lain karena alasan sebagai berikut [4],[7],[10]:

1. Struktur dengan model hirarki. Disini merupakan hasil dari kriteria yang dipilih yang mencapai hierarki bawah terdalam.

2. Mempertimbangkan validitas hingga batas toleransi berbagai kriteria dan alternatif yang dipilih oleh pembuat kebijakan.

3. Mempertimbangkan keberlanjutan atau resistensi dari output analisis sensitivitas pengambilan keputusan. 


\section{Journal of Computer and Information Systems Ampera}

Vol. 2, No. 2, May 2021 e-ISSN: 2775-2496

https://journal-computing.org/index.php/journal-cisa/index

\subsection{Prinsip Dasar Analitycal hierarchy process (AHP)}

Pada prinsipnya, langkah-langkahnya termasuk dalam metode AHP meliputi [11],[12]:

1. Membuat Hierarki. Masalah yang harus selesaikan, dipecah menjadi elemen-elemen, yaitu kriteria dan alternatif, kemudian disusun dalam struktur hierarkis.

2. Penilaian kriteria dan alternatif. Untuk berbagai masalah, skala dari 1 hingga 9 adalah skala terbaik untuk mengekspresikan pendapat. Nilai kualitatif dan definisi skala perbandingan.

3. Penentuan Prioritas (Synthesis Of Priority). Diperlukan perbandingan pasangan-bijaksana untuk setiap kriteria dan alternatif. Nilai perbandingan relatif kemudian diproses untuk menentukan peringkat alternatif untuk semua alternatif.

4. Konsistensi Logis (Logical Consistency). Konsisten memiliki dua makna. Pertama, objek yang sebanding dapat dikelompokkan berdasarkan keseragaman dan relevansi. Kedua, berkaitan dengan tingkat hubungan antar objek berdasarkan kriteria tertentu.

A. Menentukan Prioritas

Saat menentukan prioritas untuk setiap kriteria dan alternatif, perbandingan pasangan harus dilakukan [13]. Nilai perbandingan relatif kemudian diproses untuk menentukan peringkat alternatif dari semua alternatif seperti pada Tabel 1 [4].

Tabel 1. Skala Penilaian Perbandingan Berpasangan

\begin{tabular}{ll}
\hline $\begin{array}{l}\text { Tingkat } \\
\text { Kepentingan }\end{array}$ & Keterangan \\
\hline 1 & $\begin{array}{l}\text { Kedua elemen sama penting. } \\
\text { Satu elemen sedikit lebih penting daripada elemen } \\
\text { lainnya. }\end{array}$ \\
5 & $\begin{array}{l}\text { Satu elemen jelas lebih penting daripada elemen } \\
\text { lainnya. }\end{array}$ \\
7 & $\begin{array}{l}\text { Satu elemen jelas lebih penting daripada elemen } \\
\text { lainnya. } \\
\text { Satu elemen sangat penting daripada elemen } \\
\text { lainnya. } \\
\text { Nilai antara dua nilai penilaian dekat satu sama lain. }\end{array}$ \\
\hline
\end{tabular}




\section{Journal of Computer and Information Systems Ampera}

Vol. 2, No. 2, May 2021 e-ISSN: 2775-2496

https://journal-computing.org/index.php/journal-cisa/index

Kebalikan

Jika aktivitas I mendapatkan satu angka dibandingkan dengan aktifitas J, maka J memiliki kebalikannya dibandingkan dengan I.

B. Keputusan Analitycal hierarchy process (AHP)

Ketika membuat keputusan, penting untuk mengetahui seberapa baik konsistensi karena kita tidak ingin keputusan berdasarkan pertimbangan konsistensi yang rendah. Hal-hal yang dilakukan antar lain [11],[14]:

1. Kalikan setiap nilai di kolom pertama dengan prioritas relatif dari elemen pertama, nilai di kolom kedua dengan prioritas relatif dari elemen kedua, dan seterusnya.

2. Jumlahkan setiap baris.

3. Hasil dari jumlah baris dibagi oleh elemen prioritas relatif relatif.

4. Tambahkan hasil bagi di atas dengan jumlah elemen, hasilnya disebut $\lambda$ max.

5. Hitung Consistency Index (CI) dengan rumus 1 berikut.

$\mathrm{CI}=\frac{(\lambda \operatorname{maks}-n)}{n-1}$

Dimana :

$\mathrm{n}$ : Banyaknya elemen berdasarkan sumber kriteria

6. Hitung Rasio Konsistensi / Consistency Index (CI) dengan rumus 2 berikut.

$\mathrm{CR}=\frac{C I}{I R}$

Dimana :

CR (Consistency Ratio) : Hasil akhir dari perhitungan

CI (Consistency Index) : Untuk mencari konsistensi index

IR (Index Random Consistency) seperti pada tabel 2.

7. Memeriksa konsisten hirarki. Jika nilainya lebih dari 10\%, maka penilaian data judgement harus diperbaiki. Namun jika rasio konsisten $\left(\frac{C I}{I R}\right) \leq 0.1$, maka hasil perhitungan bisa dinyatakan benar [14].

Tabel 2. Nilai Index Random (IR)

\begin{tabular}{llllll}
\hline $\begin{array}{l}\text { Ukuran } \\
\text { Matriks }\end{array}$ & Nilai IR & $\begin{array}{l}\text { Ukuran } \\
\text { Matriks }\end{array}$ & Nilai IR & $\begin{array}{l}\text { Ukuran } \\
\text { Matriks }\end{array}$ & Nilai IR \\
\hline $\mathbf{1 , 2}$ & 0.00 & $\mathbf{7}$ & 1.32 & $\mathbf{1 2}$ & 1.53 \\
$\mathbf{3}$ & 0.58 & $\mathbf{8}$ & 1.41 & $\mathbf{1 3}$ & 1.56 \\
$\mathbf{4}$ & 0.90 & $\mathbf{9}$ & 1.45 & $\mathbf{1 4}$ & 1.57 \\
$\mathbf{5}$ & 1.12 & $\mathbf{1 0}$ & 1.49 & $\mathbf{1 5}$ & 1.59 \\
\hline
\end{tabular}




\section{Journal of Computer and Information Systems Ampera}

Vol. 2, No. 2, May 2021 e-ISSN: 2775-2496

https://journal-computing.org/index.php/journal-cisa/index

\begin{tabular}{llll}
\hline $\mathbf{6}$ & 1.24 & $\mathbf{1 1}$ & 1.51 \\
\hline
\end{tabular}

C. Pola Pikir Penelitian

Kerangka berfikir dalam penelitian ini menggunakan alat bantu untuk menampilkan baik proses dan keputusan logis dalam proses nyata yang melibatkan input output maupun dalam aliran data seluruh sistem seperti pada gambar1 berikut.

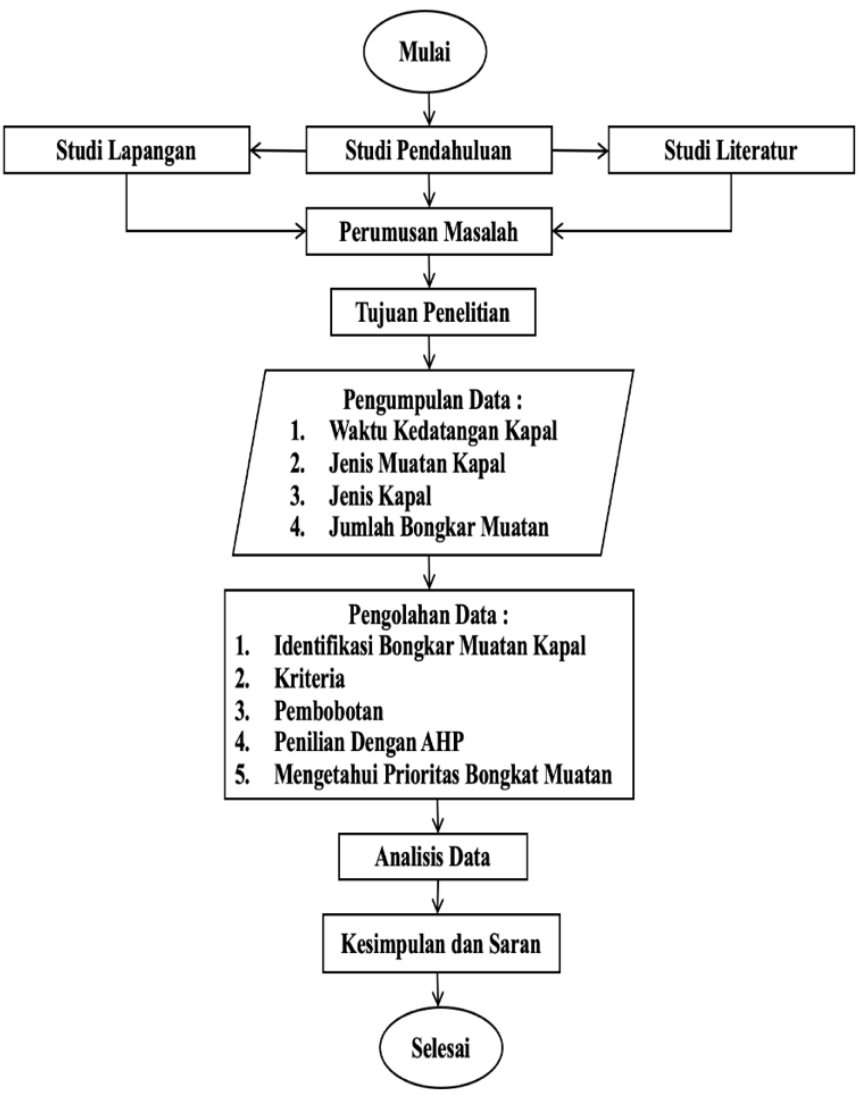

Gambar 1. Kerangka Penelitian

\section{HASIL DAN PEMBAHASAN}

Ada 4 Kriteria yaitu yaitu waktu kedatangan kapal (A), jenis muatan (B), jenis kapal (C), jumlah bongkar (D) seperti pada tabel 4. Setelah data terkumpul dari responden maka selanjutnya dihitung rata-ratanya dengan menggunakan rata-rata geometrik [15]. Untuk lebih jelas mengenai rata- 


\section{Journal of Computer and Information Systems Ampera}

Vol. 2, No. 2, May 2021 e-ISSN: 2775-2496

https://journal-computing.org/index.php/journal-cisa/index

rata dapat dilihat pada tabel 3 berikut, sedangkan untuk hirarki pemilihan prioritas bongkar muatan kapal dapat dilihat pada Gambar 3.

Tabel 3. Lampiran Hasil Rata-Rata Geometri Antar Kriteria

\begin{tabular}{l|l|l|l|l|l|l}
\hline No & A vs B & A vs C & A vs D & B vs C & B vs D & C vs D \\
\hline 1 & 1 & 9 & 1 & 1 & 1 & 1 \\
2 & 9 & 7 & 9 & 9 & 9 & 9 \\
3 & 9 & 9 & 9 & 9 & 9 & 9 \\
4 & 3 & 7 & 3 & 3 & 3 & 3 \\
5 & 0.14 & 3 & 0.14 & 0.14 & 0.14 & 0.14 \\
6 & 9 & 2 & 9 & 9 & 9 & 9 \\
7 & 3 & 3 & 3 & 1 & 1 & 3 \\
8 & 1 & 9 & 1 & 1 & 1 & 1 \\
9 & 9 & 7 & 9 & 9 & 9 & 9 \\
\hline Total & 3.94 & 5.48 & 3.94 & 3.44 & 3.44 & 3.94 \\
\hline
\end{tabular}

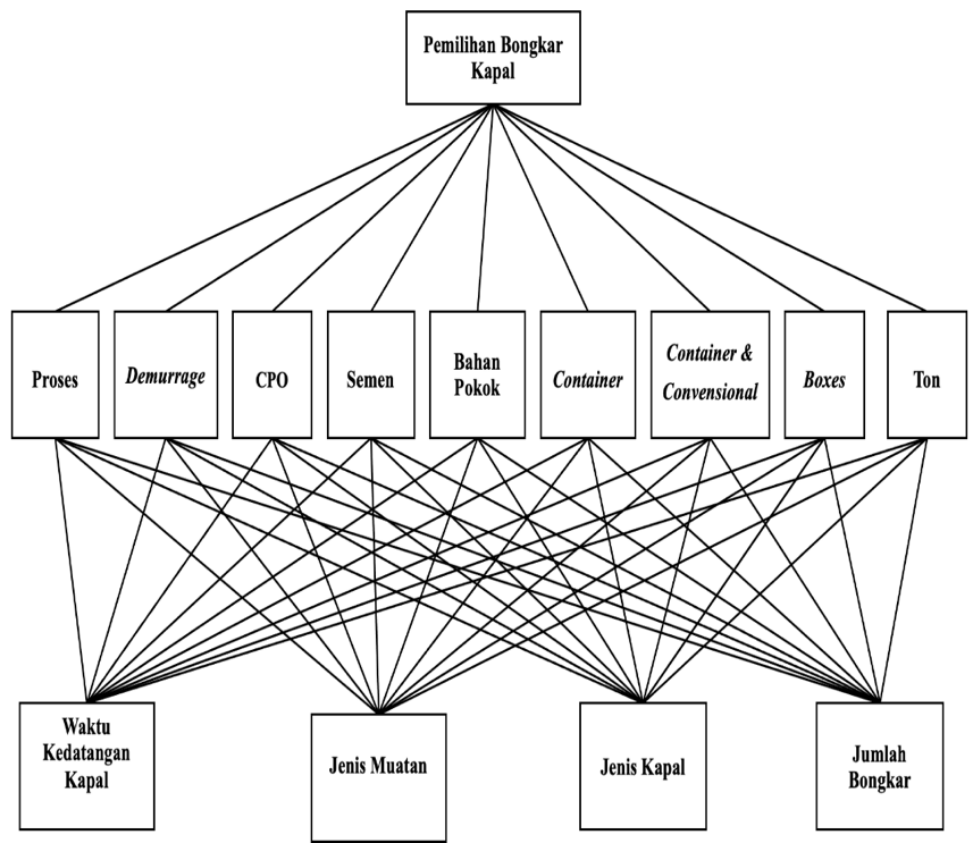

Gambar 2. Hirarki Pemilihan Bongkar Muat isi Kapal

Tabel 4. Kriteria Pemilihan Bongkar Kapal

No. Kriteria




\section{Journal of Computer and Information Systems Ampera}

Vol. 2, No. 2, May 2021 e-ISSN: 2775-2496

https://journal-computing.org/index.php/journal-cisa/index

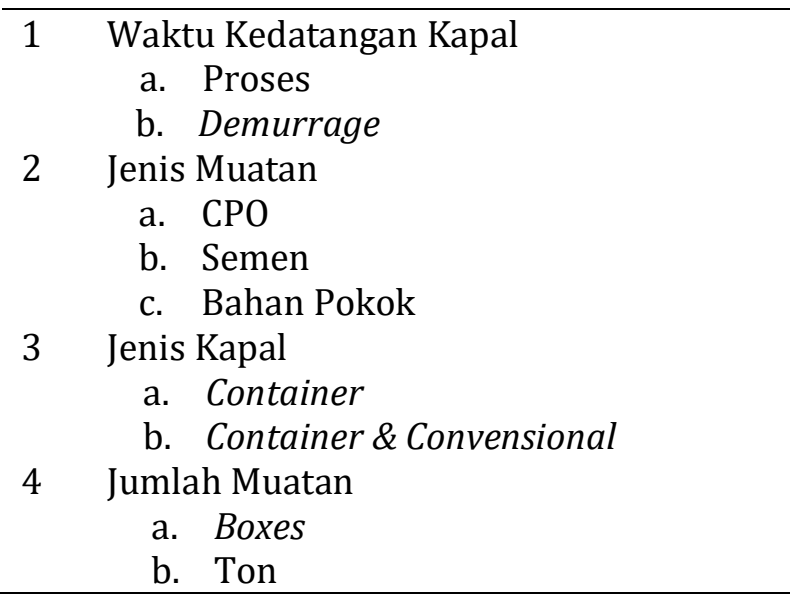

A. Membuat Matriks Perbandingan Pada Setiap Kriteria Langkah pertama adalah membuat matriks perbandingan yang dijalankan dengan membandingkan kriteria dengan kriteria seperti yang ditunjukkan pada Tabel 5 di bawah ini.

Tabel 5. Matrik Berpasangan Pada Setiap Kriteria

\begin{tabular}{lllll}
\hline & A & B & C & D \\
\hline A & 1 & 2 & 5 & 2 \\
B & 0.5 & 1 & 3 & 2 \\
C & 0.2 & 0.33 & 1 & 2 \\
D & 0.5 & 0.5 & 0.5 & 1 \\
\hline Jumlah & 2.20 & 3.83 & 9.50 & 7.00 \\
\hline
\end{tabular}

B. Membuat Matriks Nilai Kriteria

Tahap kedua ini yaitu membut matriks nilai kriteria untuk menentukan prioritas dari masing-masing kriteria seperti pada tabel 6.

Tabel 6. Matrik Nilai Kriteria

\begin{tabular}{lllllll}
\hline & A & B & C & D & Jumlah & Prioritas \\
\hline A & 0.45 & 0.52 & 0.53 & 0.29 & 1.79 & 0.45 \\
B & 0.23 & 0.26 & 0.32 & 0.29 & 1.09 & 0.27 \\
C & 0.09 & 0.09 & 0.11 & 0.29 & 0.57 & 0.14 \\
D & 0.23 & 0.13 & 0.05 & 0.14 & 0.55 & 0.14 \\
\hline
\end{tabular}

C. Membuat Matriks Penjumlahan Tiap Baris

Tahap ketiga ini yaitu membuat matriks penjumlahan setiap baris dari setiap kriteria yang ada seperti pada tabel 7 . 


\section{Journal of Computer and Information Systems Ampera}

Vol. 2, No. 2, May 2021 e-ISSN: 2775-2496

https://journal-computing.org/index.php/journal-cisa/index

Tabel 7. Matrik Penjumlahan Setiap Baris

\begin{tabular}{llllll}
\hline & A & B & C & D & Jumlah \\
\hline A & 0.45 & 0.54 & 0.71 & 0.28 & 1.98 \\
B & 0.22 & 0.27 & 0.43 & 0.28 & 1.20 \\
C & 0.09 & 0.09 & 0.14 & 0.28 & 0.60 \\
D & 0.22 & 0.14 & 0.07 & 0.14 & 0.57 \\
\hline
\end{tabular}

D. Perhitungan Rasio Konsistensi

Tahap keempat yaitu melakukan perhitungan rasio konsistensi (CR) dari setiap kriteria sehingga diperoleh total 17.15 . Nilai ini nantinya akan digunakan dalam proses $\lambda$ maks seperti tabel 8 .

Tabel 8. Perhitungan Rasio Konsistensi

\begin{tabular}{llll}
\hline & Penjumlahan per baris & Prioritas & Hasil \\
\hline A & 1.98 & 0.45 & 4.43 \\
B & 1.20 & 0.27 & 4.40 \\
C & 0.60 & 0.14 & 4.21 \\
D 0.57 & 0.14 & 4.11 \\
\hline Jumlah & & 17.1 \\
& & 5 \\
\hline
\end{tabular}

Perhitungan ini digunakan untuk memastikan bahwa nilai rasio konsistensi $(\mathrm{CR})<=0.1$, jika ternyata $\mathrm{CR}>0.1$ maka matriks perbandingan harus diperbaiki [16],[17].

Dik : $\quad n=4$ (jumlah kriteria)

$$
\text { Jumlah }=17.15
$$

Dit : Hitung $\lambda$ maks ?

Hitung CI ?

Hitung CR ?

Penyelesaian :

$$
\begin{aligned}
& \lambda \text { maks }=\left(\frac{\text { jumlah }}{n}\right)=\left(\frac{17.15}{4}\right)=4.29 \\
& \mathrm{CI}=\left(\frac{\lambda \text { maks }-n}{n}\right)=\left(\frac{4.29-4}{4}\right)=0.07 \\
& \mathrm{CR}=\frac{C I}{I R}=\frac{0.07}{0.90}=0.08
\end{aligned}
$$

Karena CR $\leq$ 0,1, rasio konsistensi perhitungan dapat diterima [16].

Tabel 9. Rekap Nilai Bobot Prioritas

Kriteria Jenis kriteria




\section{Journal of Computer and Information Systems Ampera}

Vol. 2, No. 2, May 2021 e-ISSN: 2775-2496

https://journal-computing.org/index.php/journal-cisa/index

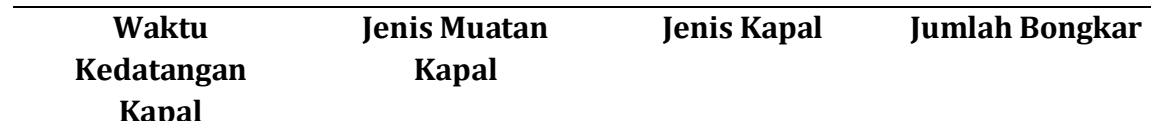

\begin{tabular}{lcccc}
\hline Proses & $0.38 \times 4.25=1.61$ & $0.27 \times 4.13=1.11$ & $0.22 \times 4.20=0.92$ & $0.13 \times 4.11=0.53$ \\
Demurrage & $0.45 \times 4.10=1.84$ & $0.26 \times 4.15=1.08$ & $0.20 \times 4.10=0.82$ & $0.09 \times 4.10=0.37$ \\
CPO & $0.50 \times 4.29=2.14$ & $0.26 \times 4.33=1.12$ & $0.16 \times 4.05=0.65$ & $0.08 \times 4.14=0.33$ \\
Semen & $0.50 \times 4.48=2.42$ & $0.29 \times 4.53=1.31$ & $0.18 \times 4.17=0.75$ & $0.03 \times 4.09=0.12$ \\
Bahan pokok & $0.38 \times 4.27=1.62$ & $0.29 \times 4.29=1.24$ & $0.21 \times 4.20=0.88$ & $0.12 \times 4.11=0.49$ \\
Container & $0.48 \times 4.48=2.15$ & $0.28 \times 4.54=1.27$ & $0.18 \times 4.17=0.75$ & $0.06 \times 4.11=0.25$ \\
Container \& & $0.45 \times 4.33=1.95$ & $0.32 \times 4.36=1.40$ & $0.15 \times 4.32=0.64$ & $0.08 \times 4.20=0.34$ \\
Convensional & & & & \\
Boxes & $0.42 \times 4.41=1.85$ & $0.36 \times 4.43=1.60$ & $0.15 \times 4.33=0.65$ & $0.08 \times 4.12=0.33$ \\
Ton & $0.42 \times 4.48=1.88$ & $0.39 \times 4.51=1.76$ & $0.13 \times 4.23=0.55$ & $0.07 \times 4.13=0.29$ \\
\hline \multicolumn{1}{c}{ Total } & 17.46 & 11.89 & 6.61 & 3.05 \\
\hline
\end{tabular}

E. Menentukan Prioritas Sub Kriteria

Tahap kelima yaitu menentukan prioritas sub kriteria (jika ada). Pada tahapan ini akan dilakukan perhitungan matriks perbandingan berpasangan setiap proses, kemudian hasilnya akan diolah menggunakan matriks nilai kriteria proses untuk menentukan prioritas yang tinggi. Adapun rekap matriks dari setiap sub kriteria dapat dilihat pada tabel 9 berikut.

Tabel 10. Rekap Matrik Perhitungan Konsistensni Setiap Faktor

\begin{tabular}{llllll}
\hline Faktor & $\begin{array}{l}\boldsymbol{\lambda} \\
\text { Maks }\end{array}$ & CI & IR & CR & Keterangan \\
\hline Proses & 4.22 & 0.05 & 0.90 & 0.07 & Konsisten \\
Demurrage & 4.11 & 0.03 & 0.90 & 0.03 & Konsisten \\
CPO & 4.20 & 0.05 & 0.90 & 0.06 & Konsisten \\
Semen & 4.22 & 0.08 & 0.90 & 0.10 & Konsisten \\
Bahan pokok & 4.32 & 0.05 & 0.90 & 0.07 & Konsisten \\
Container & 4.32 & 0.08 & 0.90 & 0.10 & Konsisten \\
Container \& Convensional & 4.30 & 0.08 & 0.90 & 0.07 & Konsisten \\
Boxes & 4.30 & 0.08 & 0.90 & 0.09 & Konsisten \\
Ton & 4.34 & 0.08 & 0.90 & 0.09 & Konsisten \\
\hline
\end{tabular}

Setelah semua matriks perbandingan level dua telah selesai dan diproses, bobot semua prioritas pada dua tingkat diperoleh yang kemudian digunakan sebagai variabel penggalian dari setiap nilai prioritas di setiap responden. Berdasarkan hasil perhitungan diatas maka dipilih nilai total 


\section{Journal of Computer and Information Systems Ampera}

Vol. 2, No. 2, May 2021 e-ISSN: 2775-2496

https://journal-computing.org/index.php/journal-cisa/index

bobot terbesar pada alternatif 1 dengan nilai total bobot 17.46 yaitu pemilihan bongkar muat kapal dengan waktu kedatangan kapal. Rekap nilai bobot prioritas hasil perhitungan dapat dilihat secara detil pada tabel 10 berikut ini. Selanjutnya hasil dari penilaian bobot prioritas ini akan digambarkan menggunakan hirarki seperti pada gambar 3 dibawah ini.

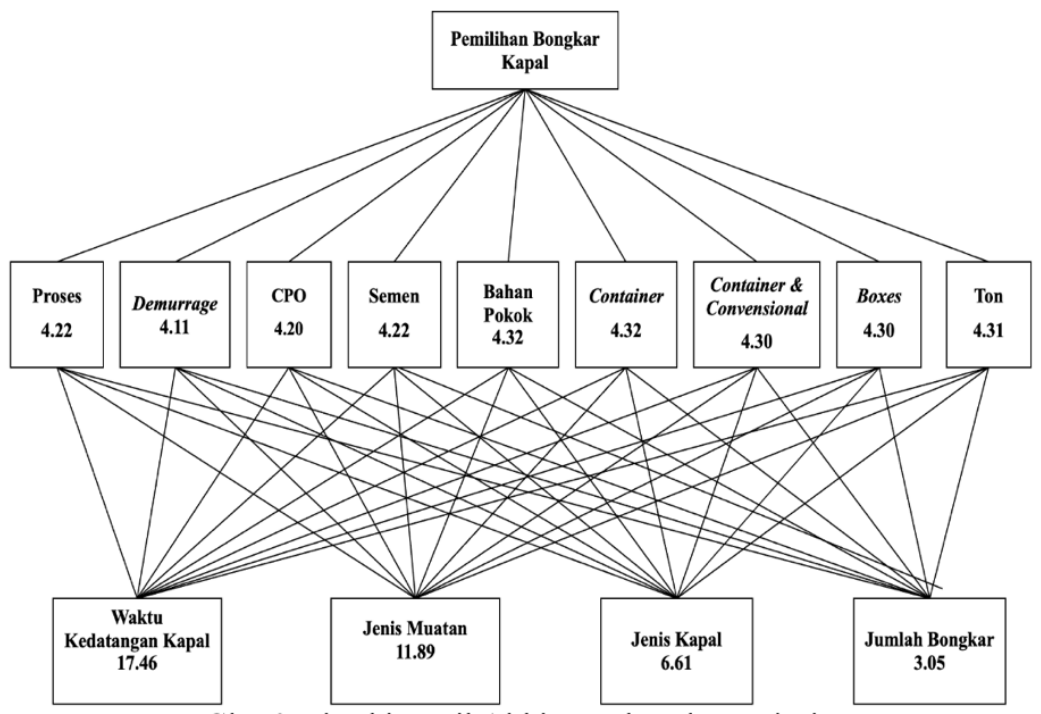

Gambar 3. Hirarki Hasil Akhir Berdasarkan Prioritas

\section{F. Analisis Hasil}

Hasil akhir yag diperoleh dalam perhitungan menggunakan metode AHP dengan nilai prioritas bobot pada AHP sebagai berikut :

1. Waktu kedatangan kapal dengan Proses nilai 1.61, Demurrage dengan nilai 1.84, CPO dengan nilai 2.14, Semen dengan nilai 2.42, Bahan Pokok dengan nilai 1.62, Container dengan nilai 2.15, Container \& Convensional dengan nilai 1.95, Boxes dengan nilai 1.85 , Ton dengan nilai 1.88 sehingga diperoleh skor total sebesar 17.46 dengan nilai tertinggi.

2. Jenis muatan kapal dengan Proses nilai 1.11, Demurrage dengan nilai 1.08, CPO dengan nilai 1.12, Semen dengan nilai 1.31, Bahan Pokok dengan nilai 1.24, Container dengan nilai 1.27, Container \& Convensional dengan nilai 1.40 , Boxes dengan nilai 1.60 , Ton dengan nilai 1.76, sehingga diperoleh skor total sebesar 11.89 . 


\section{Journal of Computer and Information Systems Ampera}

Vol. 2, No. 2, May 2021 e-ISSN: 2775-2496

https://journal-computing.org/index.php/journal-cisa/index

3. Jenis kapal dengan Proses nilai 0.92, Demurrage dengan nilai 0.82, CPO dengan nilai 0.65, Semen dengan nilai 0.75, Bahan Pokok dengan nilai 0.88, Container dengan nilai 0.75, Container \& Convensional dengan nilai 0.64 , Boxes dengan nilai 0.65 , Ton dengan nilai 0.55 , sehingga diperoleh skor total sebesar 6.61.

4. Jumlah muatan dengan Proses nilai 0.53, Demurrage dengan nilai 0.37, CPO dengan nilai 0.33, Semen dengan nilai 0.12, Bahan Pokok dengan nilai 0.49, Container dengan nilai 0.25, Container \& Convensional dengan nilai 0.34, Boxes dengan nilai 0.33, Ton dengan nilai 0.29, sehingga diperoleh skor total sebesar 3.05.

Hasil bobot prioritas masing-masing faktor yaitu faktor Proses sebesar 4.22, faktor Demurrage sebesar 4.11, CPO sebesar 4.20, Semen sebesar 4.22, Bahan pokok sebesar 4.32, Container sebesar 4.32, Container \& Convesional sebesar 4.30, Boxes sebesar 4.30 dan Ton sebesar 4.31. Sehingga diperoleh nilai bobot prioritas terbesar adalah bahan pokok yang harus dibongkar terlebih dahulu sebesar 4.32.

\section{KESIMPULAN}

Berdasarkan hasil penelitian dan pengujian, faktor yang menjadi pemilihan bongkar muat kapal adalah waktu kedatangan kapal, jenis muatan kapal, jenis kapal dan jumlah bongkar kapal. Bobot prioritas masing-masing faktor yaitu faktor proses sebesar 4.22, faktor demurrage sebesar 4.11, faktor CPO sebesar 4.20, faktor semen sebesar 4.22, faktor bahan pokok sebesar 4.32, faktor container sebesar 4.32, faktor container \& convensional sebesar 4.30, faktor boxes sebesar 4.30, faktor ton sebesar 4.31. Sehingga, Berdasarkan hasil perhitungan empat alternatif maka total bobot prioritas pemilihan bongkar muat yaitu berdasarkan waktu kedatangan kapal (17.46), jenis muatan (11.89), jenis kapal (6.61), dan jumlah bongkar (3.05).

\section{DAFTAR PUSTAKA}

[1] A. Muzakir and H. Hutrianto, "Bellman-Ford Algorithm for Completion of Route Determination: An Experimental Study," 2020.

[2] D. Apriliani, S. Wiyono, S. Mahardhika, J. Teknik Informatika, P. Harapan Bersama, and J. Mataram No, "Penerapan Metode Weighted Product Untuk Sistem Pendukung Keputusan Penerima Beasiswa Politeknik Harapan Bersama Tegal," J. Inform. Pengemb. IT, vol. 03, no. 02, pp. 136-142, 2018. 


\section{Journal of Computer and Information Systems Ampera}

Vol. 2, No. 2, May 2021 e-ISSN: 2775-2496

https://journal-computing.org/index.php/journal-cisa/index

[3] N. H. Ahmad, W. Wahyani, and A. S. Sastriadi, "Analytical Hierarchy Process (AHP) Sebagai Dasar Pemilihan Pemasok (Supplier) dan Penentuan Anggaran Pembiayaan Bahan Baku di CV. Karya Bahari Surabaya," Karya Bahari Surabaya. Jur. Tek. Ind. Univ. Muhamadiyah Sidoarjo, 2013.

[4] H. P. Adi, "Penentuan Prioritas Pembangunan Pelabuhan di Kabupaten Mukomuko dengan Metode Analytical Hierarchy Process," MEDIA Komun. Tek. SIPIL, vol. 16, no. 2, pp. 117-129, 2008.

[5] G. Ramayanti and D. H. Ulum, "Sistem Penentuan Supplier Kawat Las Dengan Metode Analitycal Hierarchy Process (AHP) dan Technique for Order Preference by Similarity to Ideal Solution (TOPSIS)," J. Sist. dan Manaj. Ind., 2017.

[6] Suyatno, "PENGGUNAAN DAN PENERAPAN TEKNOLOGI INFORMASI SEBAGAI SISTEM PENDUKUNG KEPUTUSAN ( SPK ) ( Studi Kasus di Lembaga Pemerintahan Daerah Kabupaten Jepara )," J. Inform. J. Pengemb. IT, vol. 1, no. 2, pp. 52-61, 2016.

[7] K. Suryadi and M. A. Ramdhani, "Sistem Pendukung Keputusan," PT Remaja Rosdakarya, Bandung, 1998.

[8] A. Muzakir and C. D. Kusmindari, "Design of Push-Up Detector Applications Using Quality Function Development and Anthropometry For Movement Error Detection," Sci. J. Informatics, vol. 5, no. 2, pp. 248-257, 2018.

[9] T. L. Saaty, "Decision making for leaders," Syst. Man Cybern. IEEE Trans., 1985, doi: 10.1109/TSMC.1985.6313384.

[10] O. S. Vaidya and S. Kumar, "Analytic hierarchy process: An overview of applications," European Journal of Operational Research. 2006, doi: 10.1016/j.ejor.2004.04.028.

[11] D. Nofriansyah, "Konsep Data Mining Vs Sistem Pendukung Keputusan," Deepublish. 2014, doi: 14 November 2017.

[12] A. S. Perdhana, W. L. Y. Saptomo, and S. Siswanti, "Sistem Pendukung Keputusan Pemilihan Jenis Laptop Dengan Menggunakan Metode Analytical Hierarchy Process," J. Teknol. Inf. dan Komun., 2013.

[13] A. Muzakir, "Algoritma Floyd Warshall Dan Collaborative Filtering Untuk Penentuan Rekomendasi Dan Rute Terpendek Pencarian Apotek: Studi Eksperimen," InfoTekJar J. Nas. Inform. dan Teknol. Jar., vol. 5, no. 1, pp. 9-13, 2020.

[14] J. A. Alonso and M. T. Lamata, "Consistency in the analytic hierarchy process: a new approach," Int. J. Uncertainty, Fuzziness KnowledgeBased Syst., 2006, doi: 10.1142/S0218488506004114. 


\section{Journal of Computer and Information Systems Ampera}

Vol. 2, No. 2, May 2021 e-ISSN: 2775-2496

https://journal-computing.org/index.php/journal-cisa/index

[15] R. D. F. S. M. Russo and R. Camanho, "Criteria in AHP: A systematic review of literature," 2015, doi: 10.1016/j.procs.2015.07.081.

[16] S. H. Saragih, "Penerapan Metode Analitycal Hierarchy Process ( Ahp ) Pada Sistem Pendukung Keputusan Pemilihan Laptop," Sylvia Hartati Saragih, 2013.

[17] S. O. Viarani and H. R. Zadry, "Analisis Pemilihan Pemasok dengan Metode Analitycal Hierarchy Process di Proyek Indarung VI PT Semen Padang," J. Optimasi Sist. Ind., 2015, doi: 2088-4842. 